е гг. (на материалах Иркутской губернии)/ Вестник Томского государственного университета. История. - 2011г. С. 120-123

7.Харитонова С. Б. Создание специального аппарата для работы среди женского населения в 1920-1930-е годы (региональный опыт)/ Вестник Чувашского университета. - 2007 г.
8.Козлов Ф. Н. «Женский вопрос» как элемент социальной политики советского государства в 1920-е - первой половине 1930-х годов (в контексте государственно-церковных отношений в национальных регионах Среднего Поволжья)/ Вестник Чувашского университета. -2013 г. С. 2936

UDC: 94(460.285):001(09)(5-015)(043.3)

\title{
THE ROLE OF THE TOLEDO AS A CENTER FOR THE TRANSFER OF SCIENTIFIC KNOWLEDGE OF MEDIEVAL EASTERN SCIENTISTS TO EUROPE
}

\section{ANNOTATION}

Makhmudov Otabek

Doctor of philosophy (PhD)

Head of Department of World History

Fergana State University

DOI: $\underline{10.31618 / E S U .2413-9335.2020 .8 .75 .890}$

In article based on the careful analysis of the scientific literature devoted to history of the translations in Spain the 12-13th centuries, opened the role of the city of Toledo as the center of distribution of scientific knowledge of scientists of the Muslim East in Europe.

Keywords: Renaissance, science, development, East and West, The Toledo School, scientists, Middle Ages, center, distribution.

\section{Introduction}

Today it is no secret that the Muslim civilization of the Middle Ages was the force that preserved ancient knowledge for Europe gave its own scientific heritage and pushed to the Renaissance.

As for the Western Renaissance itself. Then you can see in history not one Renaissance, not one Renaissance, but several. Renaissance of the XII century, which was caused by familiarity with the Muslim educational system and science. The Renaissance of the XV century, caused by the return to art, architecture and literature of ancient standards, which, again, were preserved for Europe by the Muslims. The Renaissance of the XVI and XVII centuries was again brought to life by Muslim scientific achievements in the field of astronomy, when the scientific concepts of Galileo and Copernicus were formed under the Islamic influence, which completely turned the entire worldview of Europeans.

While the middle ages in European culture are associated with all the darkest, wildest, barbarian and backward, these same middle ages for the Muslim world were the period of the highest rise and civilizational flourishing.

For several centuries, Baghdad, Damascus, Merv, Bukhara, Khorezm, and Samarkand were the intellectual centers of the entire world. These cities were the center of the largest communities of scholars, translators, scribes and book publishers engaged in the development of Muslim science, the study of the heritage of previous civilizations and its reinterpretation within the framework of Islamic traditions [8, p. 24].

The scholars of the Muslim East, who produced an incredibly powerful intellectual civilization, were admired by neighboring peoples. The desire to touch their cultural, scientific, intellectual, spiritual and material treasures was widespread among Europeans.
Introduction to the Muslim heritage and its development by Europeans began, first of all, in the border areas where the Western and Muslim worlds touched - in Andalusia, southern France and Italy, as well as in the middle East during the Crusades.

This process of cultural and scientific exchange between Muslims and Europeans has been growing and developing continuously for several centuries. At the dawn of the Renaissance, Christian Europe wore Eastern clothing, sang songs in Arabic, studied astronomy and mathematics based on the works of alKhwarizmi and al-Ferghani, read the philosophical works of al-Farabi, Avicenna, al-Ghazali, expanded his medical knowledge with the help of the works of arRazi and Avicenna [2, p. 15].

The topic of how deep the influence of Muslim civilization had on medieval Europe is quite wide open. Therefore, we will focus only on some of its most interesting aspects.

In the XII - XIII centuries, the Spanish city of Toledo played the role of a kind of transit point for the transfer of highly developed Muslim science to medieval Christian Europe. Based on the results of our doctoral research on the topic "Studying the scientific heritage of Eastern scientists in the translation centers of medieval Europe", we want to reveal the role of this city as a center for the transfer of scientific knowledge of Eastern scientists in Europe.

\section{Results of a research}

Toledo is called the city of three cultures: Christian, Islamic and Jewish. Co-existing in this city for centuries, each of the cultures has brought unique features to it.

"When God created the sun, he placed it over Toledo," says an ancient legend. But the exact date when this ancient city was founded, history has not preserved. Toledo appeared early on the historical 
scene perhaps that is why so many romantic legends are told about it more than about other Spanish cities.

In the "Toledo annals" of the XII century, it is written that "from the beginning of the world to the construction of the city of Toledo -4113 years. Darius, king of Rome, sent Solomon and Brutus to Spain to find a better place to build a better city, so that it would be the capital of all Spain. As they were commanded, they went all over Spain, and near the river Tagus, they found a place like to which there was none in all Spain: for it was such as the king had told them of; and they began to build a city, and in the seventh year they completed it. Then they sent their messengers to their master [with the question]: what should I call him? When the king heard this, he rejoiced with great joy, and said: "Let the said consuls take seven letters from their names, the first five from the name of Tolemon, and the last two from the name of Bruto, and put them together to make one word and one name." So the letters were put together and the name came out Toledo. As a result of these actions, Toledo received its name; in addition, the said king called it a Royal city".

Titus Livy wrote about this city in his work "History of Rome". Speaking about the conquest of the Iberian Peninsula by the Romans, the historian reports the capture in 193 BC of a small, but inaccessible due to its location, the town of Toletum, which surrendered only after persistent resistance [8, p. 14].

In General, during the reign of the Romans, Toledo was one of the main commercial and administrative centers of the ancient Roman province of Tarracona Spain. In modern Toledo, there are some traces of Roman civilization, such as the aqueduct, the base of which can be seen on both banks of the Tagus river, the remains of a Roman road on the slopes of the left Bank, as well as a circus located in a public Park and many other archaeological sites that are still found from time to time during excavations.

Roman rule was replaced by barbarian invasions, and Toledo became the capital of the Visigothic Kingdom in 534. The Visigoths who captured Toledo and later adopted the Christian religion used Roman buildings as materials for building churches and monasteries. As the capital of the Visigothic Kingdom, Toledo became one of the main cities in Europe.

The Jews who have inhabited this territory since ancient times were only recognized in 712 , when the city was captured by the Moors. The Arab conquest lasted 373 years, a relatively short period, but the impact they had on the city was enormous. The period of the Moors rule was truly a Golden age for Toledo. Intensive inter-ethnic contacts in conditions of religious tolerance led to a rapid flourishing of culture. Jews, Christians, and Muslims coexisted peacefully in the city. In 1035, after the collapse of the Cordova Caliphate into many independent Emirates, Taif of Toledo became the capital of one of the wealthiest taifs in the Muslim Kingdom of al-Andalus. Because of its Central position on the Iberian Peninsula, Toledo was at the heart of the Spanish Reconquista, conflicts and wars between the Muslim and Christian leaders of Northern Spain [8, p. 27].
In 1085, when king Alfonso VI took the city without shedding a single drop of blood, many Muslims decided to stay with the Christians and Jews. The result of this harmonious co-existence was, for example, the famous Toledo school of Translators.

In the XII - XIII centuries, the city of Toledo, then the capital of Spain, the center of scientific thought and cultural life of this country was at the center, in modern terms, of a large-scale cultural project, which was called the Toledo school of translators. The school brought together people who were fluent in Arabic and Latin - at that time the only language of international communication in Europe - and worked together, following some common principles and methods of translation.

Toledan translators for almost two centuries introduced scientists in Spain and other European countries to the works of prominent Greek and Muslim philosophers, mathematicians, doctors, botanists, and astronomers. They performed, for example, translations from Arabic to Latin of the commentaries of the Greek thinkers Aristotle and Plato, which were made by alFarabi and Avicenna [1, p. 8].

The number of translations into Latin of the works of scientists of the Muslim world, which were then far ahead of European scientific thought, is impressive. Translations from the pen of toledan interpreters not only had a significant impact on the development of medieval European culture and science, but also contributed, among other factors, to the creation of a national Spanish language in Castile [5, p. 5-6].

Before translations made within the walls of the Toledo school of translators appeared and began to spread throughout Europe, European universities were fed mainly by Roman sources. Moreover, although in Europe, of course, they knew about the existence of the works of Greek philosophers and Muslim scientists, the lack of translations of their works into Latin led to the fact that the content of these books remained unknown to Europeans.

There are four historical stages in the activity of the Toledo school. The first stage covers approximately from 1105 to 1125 . Characterized by an interest primarily in works on astrology, astronomy and mathematics, but a chaotic choice of works for translation. The translation itself is often a capacious summary or summary of a scientific book without specifying the author and translator. Such treatises remained anonymous, but gradually spread throughout Europe. The second stage is associated with the name of Archbishop Raimondo de Salveta [6, p. 534]. This stage covers from 1126 to 1151 . It is characterized by a more organized, but still focused around translations of works in mathematics, astronomy, astrology, medicine. We can judge the role of Archbishop Raimondo from the dedications at the beginning of the books addressed to him. Some historians place the figure of Archbishop Raimondo above all participants in the translation movement, while others assign him only a minor role as a coordinator who passed on "orders" from the educated elite to translate certain works. Some translators belonged to certain groups of enlightened 
people United by friendship, while others worked more separately, not belonging to any of the groups [2, p. 15].

At this time, Toledo attracts seekers of Eastern Muslim wisdom, indefatigable scribes and great workers from different countries of Europe, who laid the Foundation for a comprehensive acquaintance of medieval Europe with authentic Muslim science and Greek classical thought, which left its imprint on the Eastern Muslim commentators.

By that time, the Iberian Peninsula had many local dialects - Vulgar Latin - Leone, Navarra, Aragon, Catalan and Castilian dialects. At the beginning of the eleventh century, the Kingdom of Castile and Leona declared the Castilian dialect the official language [7, p. 4]. Latin exists separately in monasteries as the language of the spiritual, secular, and cultural elite. Naturally, many simple and learned people spoke Arabic. It is believed that some translators worked in pairs - one interpreter performed interpretation from Arabic into romance (Castilian dialect), the other recorded the text in Latin. At least, this is evidenced by some prefaces and dedications of translations, which mention the names of two translators and specify who translated from Arabic to Castilian and from Castilian to Latin. The third stage covers the period from 1152 to 1252. With great reason, we can call this stage as the "Toledo school", due to a certain organization, greater centralization and communication of translators with each other. The administration and patronage of the school are associated with the names of archbishops John (1152 - 1166) and Rodrigo Jimenez de Rada (1202 - 1247). During this period, attention is drawn to the search for metaphysical principles that formed the system of scientific knowledge of Muslim scientists, to the philosophical works of al-Farabi, al-Ghazali, Avicenna, Ibn Gebirol, and finally to the source of their inspiration - the works of Aristotle [2, p. 15]. The fourth stage in the activity of the Toledo school begins with the accession to the throne in 1252 of King Alfonso X the Wise, and continues until 1284. Alfonso $\mathrm{X}$, being a highly educated and versatile person, gave a new impetus to the work of the school of translators. He was interested in exact Sciences, history, law, literature, and languages. Alfonso $\mathrm{X}$ translated a lot himself and even edited translations made by other translators. Some Spanish historians believe that the notes in the margins of the surviving translation manuscripts belong to the hand of Alfonso X. The king personally supervised the work of the school, selected people for translation work, found works for translation, and participated in discussions about translation methods. Under Alfonso X, Arabic treatises on physics, alchemy, and mathematics were translated [7, p. 3-7].

Under Alfonso X, Toledo rose even higher in importance as a center for translation, as well as for writing original scientific works. The king's decision to leave Latin as a learned language for translations and use a repeated vernacular version of the Spanish literary language had very significant consequences on the development of the first foundations of the Spanish language.
Scholars from countries such as Italy, Germany, England, or the Netherlands who moved to Toledo to translate medical, religious, classical, and philosophical texts returned to their countries with acquired knowledge from classical Arabic, classical Greek, and ancient Hebrew.

Translation methods developed under the guidance of Alfonso X. Previously, a native speaker would have verbally reported the contents of the books to a scholar, who would dictate its Latin equivalent to the scribe who wrote down the translated text. Under the new methodology, a translator, with expertise in several languages dictated from the main language, translating into Spanish for the scribe who wrote the Spanish version. The scribe's work was later reviewed by one or more editors.

The main translators of the Toledo school are John of Seville, Domingo Gundisalvi, Ibn Daud, Rudolph of Bruges, John of Spain, Michael Scot, Mark of Toledo, Herman of Germany, Yehuda Ben Moshe Cohen, Isaac ibn Sid, Abraham of Toledo, Alvaro de Oviedo, Juan de Aspa, Gulien Arremon, Petro de Regina, Edegio de Parma [2, p. 14-21].

Some translators belonged to certain groups of enlightened people United by friendship, while others worked more separately, not belonging to any of the groups.

Translators of the Toledo school for almost two centuries introduced European scientists to the works of outstanding Greek-Roman thinkers such as Hippocrates (460-370), Aristotle (384-322), Euclid (325-265), Archimedes (287-212), Galen (129-200) [1, p. 5-9], as well as famous Muslim astronomers, mathematicians, doctors, botanists, chemists, such as Jabir ibn Hayyan (721-815), at-Tabari (w.b. 762), Sahl ibn Bishr (786-845), al-Hayat (770-835), alKhwarizmi (783-850), al-Balkhi (787-886), alFarghani (798-865), al-Kindi (800-873), Hunayn ibn Ishaq (809-877), Qusta ibn Luqa (820-912), Sabit ibn Kurra (836-901), al-Hasan (IX century), Abu Kamil (850-930), al-Battani (858-930), al-Kabisi (d. 967), alRazi (865-925), al-Farabi (873-950), al-Sufi (903986), al-Majriti (d. 1008), al-Zahrawi (936-1013), alHaytham (965-1040), Avicenna (980-1037), al-Misri (988-1061), al-Wafid (997-1074), al-Zarkali (10291087), al-Ghazali (1058-1111), al-Bitruji (d. 1204), Jabir ibn Aflan (1100-1150), etc [5, p. 5-20].

\section{Conclusions}

The legacy of translators in various Sciences, such as astronomy, astrology, algebra, medicine, chemistry, philosophy, and history, has acted as a magnet for numerous scientists from all regions of Europe who have come to Toledo seeking to learn firsthand about the contents of all those books that have been beyond the reach of Europeans for centuries. Thanks to this group of scholars and writers, the knowledge acquired from Muslim, Greek, and Hebrew texts has found its way into the heart of European universities.

Only the transfer to Europe of Arabic numerals and the system of counting, which were formed in the works of al-Khwarizmi, led to a revolution in the knowledge of Europeans in mathematics, algebra, geometry, based on which the teaching system, 
architecture, trade, economy and the subsequent prosperity of the whole of Europe were further developed [4, p. 3-7].

In the fourteenth century, toleration was put to an end. The persecution of Jews and the desire of Catholic kings to Christianize and suppress Muslims and Jews led to the Inquisition. The Jews were expelled from the city, but later the Catholic kings allowed them to return to the Jewish quarter of Toledo in return for paying taxes. The inquisitors severely punished those who refused to convert to the Christian faith.

In the first half of the XVI century, under King Charles I, Toledo became the seat of the Royal court and virtually the entire United Spain. However, in 1563, King Philip II moved the capital and seat of the Royal court to Madrid, and Toledo gradually began to lose its political power and privileges. The city's economy declined. A few years in Toledo was raging epidemics of plague and cholera. The city gradually became poorer, and the palaces that were once the luxurious residences of Catholic and Muslim kings became the property of various religious orders. The seventeenth century was a brief period of small economic growth in Toledo. This was mainly due to the advent of the Enlightenment and the establishment of a number of trading companies and factories in Toledo, as well as a weapons factory.

In the XIX century, the rapid growth of the city began and, as a result, the modernization and improvement of its infrastructure - water supply appeared in buildings, and power plants were built on the banks of the Tagus River. In addition, Toledo was one of the first cities to have a railway.

During the civil war of the early twentieth century, Toledo suffered greatly. During the siege, the ancient Alcazar Palace, which served as the residence of Muslim and later Catholic kings, was almost destroyed. Currently, the Palace has been completely restored.

In 1986, Toledo was declared a UNESCO world heritage city. Modern Toledo is one of the most visited cities in Spain. In this city, first, the opportunity to touch the thousand-year history of the city attracts. Toledo is the capital of the province of the same name, as well as the Autonomous region of Castile-La Mancha. The population of the city is about 80 thousand inhabitants. In 1986, Toledo was declared a
UNESCO world heritage city for its rich cultural and monumental heritage.

\section{References}

1.Махмудов О. В. Феномен Толедской школы и три этапа переводов // Евразийский Союз Ученых. - 2017. - №. 12-1 (45). C. 5-9 [Makhmudov O. V. The phenomenon of the Toledo school and the three stages of translation // Eurasian Union of Scientists. 2017; 121 (45): 5-9 (in Russ)].

2.Махмудов О. В. Феномен Толедской школы и четыре этапа переводов // Всеобщая история. 2017. - №. 3. - C. 14-21 [Makhmudov O. V. The phenomenon of the Toledo school and the four stages of translation // General History. 2017; (3): 14-21. (in Russ)].

3.Burnett C. The Coherence of the Arabic-Latin Translation Program in Toledo in the Twelfth Century // Science in Context. 2001; (14): 249-288.

4.Makhmudov O. V. Some reasons about employees of the translator Domingo Gundisalvo in Toledo School // Austrian Journal of Humanities and Social Sciences. 2017; (1-2): 3-7.

5.Makhmudov O. V. Translations carried out in the Spanish translation centers (On basis of the works of scientists of antiquity and Muslim east) // Asian Journal of Multidimensional Research (AJMR). 2017; (6-2): 5-20.

6.Makhmudov O. Latin translations of the works Abū Bakr ar-Rāzī and their values in development of the modern sciences // History, Problems and Prospects of Development of Modern Civilization. 2017; (18): 534-538.

7.Makhmudov O. V. Toledo School in the period of King Alfonso $X / /$ Proceedings of the $1^{\text {st }}$ International Conference on History, Sociology and Philosophy. - Vienna, 15 January 2017. P. 3-7.

8.Makhmudov O. V. The Toledo School - early center of investigation of the works Central Asian scholars in the Europe. - Saarbrucken: Lambert Academic Publishing, 2017. ISBN: 978-3-330-334052.

9.Pym A. The Price of Alfonso's Wisdom. Nationalist Translation Policy in Thirteenth-Century Castile // The Medieval Translator / Traduire au Moyen Age 5. 1996; (4): 448-467. 